\title{
THE IMPORTANCE OF FINANCIAL MOTIVATORS IN THE EMPLOYEE MOTIVATION IN ENTERPRISES OF THE REGION OF KONIN
}

\begin{abstract}
Motivating issues concern every organization, primarily due to the variety of available motivators and the difficulties resulting from their use, in particular those related to the needs and employee's expectations. At the same time, every motivational system consisting of financial and non-financial motivators generates financial costs for the enterprise. Regardless of the types of motivators used, managers need to prepare the enterprise for bearing specific financial outlays. Therefore, it is necessary to look for motivators that will not only gain employee's acceptance, but, above all, will affect their commitment in achieving the goals that the organization seeks to achieve and at the same time will be an optimal financial burden for the company. An important role in the whole process is played by financial motivation, which is associated with financial expenditures borne by the company, but at the same time it is able to stimulate employees to work effectively. The use of motivators in enterprises may result from the application of various systems and may not always lead to undertaking effective actions on the market. The aim of the study is to present the use of financial motivators in enterprises in the Konin region in the opinion of employees. The paper hypothesizes that motivators in enterprises are an important element of the process of motivating employees, and employers most often apply the settlement of employees for the results and the allocation of bonuses associated with them.
\end{abstract}

Keywords: motivation, company, employee, finances.

\section{INTRODUCTION}

The ability to motivate employees to work is one of the most important components of broadly understood managerial qualifications ${ }^{2}$. At the same time, each manager has great opportunities to stimulate and consolidate the motivation of employees working in his team. It can motivate by creating higher wealth, the employees' interest in the tasks they perform, by creating promotion prospects, better working conditions, greater opportunities to parti-

\footnotetext{
${ }^{1}$ Agnieszka Szymankowska, PhD, Department of Finance, Accounting and Logistics, Social and Technical Department, State University of Applied Sciences in Konin, 62-510 Konin, ul. Przyjaźni 1; e-mail: a.szymankowska@pwsz.konin.edu.pl.

Dr Agnieszka Szymankowska, Katedra Finansów, Rachunkowości i Logistyki, Wydział Społeczno-Techniczny, Państwowa Wyższa Szkoła Zawodowa w Koninie, 62-510 Konin, ul. Przyjaźni 1; e-mail: a.szymankowska@pwsz.konin.edu.pl.

${ }^{2}$ L. Kozioł, A. Piechnik-Kurdziel, J. Kopeć, Zarządzanie zasobami ludzkimi. Teoria i praktyka, Warszawa 2006, s. 220-221.
} 
cipate in the management, or providing them with greater freedom in performing tasks ${ }^{3}$. Financial motivators are an important factor motivating employees, especially because of the authentic possibility of linking them with the implementation of specific goals necessary to achieve within a set time. It should be noted that today's enterprises are looking for a variety of elements that can affect subordinates' engagement and contribute to the increase of the company's efficiency.

In connection with the above, all actions taken by the manager should be aimed at increasing employee involvement in the implementation of tasks and striving to achieve specific goals. The managers should at the same time, consciously implement the policy of motivating and carefully choose the motivators that will help in meeting the needs of employees, which will result in a better functioning of the department or even the entire enterprise.

\section{THE ESSENCE OF THE EMPLOEE'S MOTIVATION}

People in the organization can be a special resource that will make it stand out in the market environment ${ }^{4}$. One of the objectives of the human resources management process is to enable management to achieve specific goals precisely through the involvement of employees $^{5}$. For this purpose, it is necessary to use the potential of employees: knowledge, skills and emotional potential properly. This, in turn, requires the design of an efficient management system ${ }^{6}$, which also includes a system for motivating employees.

The concept of motivation is related to the psychological state, which affects the level of human involvement in a particular activity. Thus, it includes factors that evoke, define and sustain people's behavior in a specific direction ${ }^{7}$. It is also possible to define this concept as an internal process that helps to set the course of action for a specific purpose ${ }^{8}$. The following interpretation can also be found in the literature: motivating is the process of conscious and deliberate influencing the behavior of people doing work by creating conditions that allow them to meet their needs, which results from their contribution to achieving specific organization goals ${ }^{9}$.

The concept of motivation is therefore identified with a specific kind of process that evokes, directs and sustains specific behaviors in order to achieve the goals set earlier. This process takes place if two conditions are met:

- the implementation of the goal must be perceived by people as useful,

- the probability of reaching the goal must be greater than zero ${ }^{10}$.

3 Ibidem, s. 222-223.

${ }^{4}$ K. Gadomska-Lila, Dopasowanie organizacyjne. Aspekt strategii, kultury organizacyjnej i zarzadzania zasobami ludzkimi, Warszawa 2013, s. 71.

5 M. Armstrong, Zarzadzanie zasobami ludzkimi, Warszawa 2011, s. 9.

${ }^{6}$ K. Gadomska-Lila, Dopasowanie organizacyjne. Aspekt strategii, kultury organizacyjnej i zarzqdzania zasobami ludzkimi, Warszawa 2013, s. 71.

7 J.A.F. Stoner, R.E. Freeman, D.R. Gilbert, jr., Kierowanie, Warszawa 2011, s. 426.

8 M. Jasiakiewicz, J.M. Soroka, Psycho-spoteczne uwarunkowania kierowania ludźmi w organizacji, Wrocław 2001, s. 58.

9 A. Pocztowski, Zarzadzanie zasobami ludzkimi. Strategie - procesy - metody, Warszawa 2012, s. 207.

${ }^{10}$ B. Pawłowska, Teorie motywacji, Łódź 2009, www.soc-org.edu.pl. 
Motivating is also a set of forces that cause specific behaviors in people. It should be a management process, leading to ensuring appropriate conditions and incentives that make the subordinate behave in accordance with the will of the manager, but what is very important, at the same time he has the sense of making independent decisions ${ }^{11}$. It is worth emphasizing that employees' motivating is primarily about identifying employees' needs, and then conscious of their activation, in order to encourage subordinates to a specific action $^{12}$. The ineffectiveness of motivation to work alone may be caused by ignorance of employees' needs or by considering and satisfying those needs that are less important to employees ${ }^{13}$.

In addition, the positive attitude of employees to work in an organization can be expected, when the natural inclinations of the people involved can translate into their behavior, thanks to specific processes and structures that have developed there ${ }^{14}$.

Human motivation can be invoked using two methods:

1) creating conditions that threaten the previous achievements of the employee - they are so-called negative incentives,

2) by providing conditions that allow to achieve a better than previously level of satisfying specific needs (can be invoked using two methods) ${ }^{15}$.

The notion of the motivating system itself is important in the analyzed problem, which is a specific arrangement of wage and personnel policy principles accepted by employees, as well as rules and procedures for awarding employees benefits for their work ${ }^{16}$. The motivational system is a collection of elements connected with each other and allowing to create conditions, and at the same time encouraging employees to fulfill their obligations resulting from the functioning of the organization. This is possible by satisfying the various needs of employees that leads to engaging to work and duties in the most desirable way in the company and at the same time giving employees personal satisfaction. Therefore, the motivation system should be built in such a way as to stimulate and consolidate positive motivation, and motivate people to enter into entrepreneurial, creative and innovative activities ${ }^{17}$.

Motivation is a continuous, complicated process that requires consistency and, at the same time, establishing clear rules. In addition, it is also necessary to know about subordinates, because a lot depends on the supervisor in this respect ${ }^{18}$. Managers have various possibilities to stimulate and consolidate employees' motivation. They can not only motivate by creating higher wages, by interest in work, through prospects for promotion, gaining better non-pay benefits, better working conditions, greater opportunities to participate in management, greater freedom of action through broadening the choice ${ }^{19}$. Recognizing the

11 A. Pocztowski, Zarzadzanie zasobami ludzkimi..., s. 426.

12 C. Zając (red.), Zarządzanie zasobami ludzkimi, Poznań 2011, s. 114.

${ }^{13}$ L. Kozioł, A. Piechnik-Kurdziel, J. Kopeć, Zarządzanie zasobami ludzkimi. Teoria i praktyka, Warszawa 2006, s. 222-223.

${ }^{14}$ M. Armstrong, S. Taylor, Zarzadzanie zasobami ludzkimi, Warszawa 2016, s. 24.

15 M. Gableta (red.), Potencjat pracy przedsiębiorstwa, Wrocław 2006, s. 85.

16 L. Kozioł, A. Piechnik-Kurdziel, J. Kopeć, Zarządzanie zasobami ludzkimi..., s. 220-221.

${ }^{17}$ Ibidem, s. 236-237.

18 D. Mamro, Motywować bez wyjątków, „Marketing w Praktyce” 2008/01, s. 92-93.

${ }^{19}$ R. Walkowiak, I.Z. Czaplicka-Kozłowska, A.J. Kozłowski, S. Stachowska, Zarzadzanie potencjatem społecznym organizacji, Olsztyn 2013, s. 113. 
individual needs of employees, they can better choose motivators that will affect their commitment to the work they do.

It should be noted that in the past employees' motivating was much easier. The employee, in fact, expected from the employer, above all, a fair remuneration adequate for the tasks performed. Currently, employees are looking for an attractive and interesting job that will also enable them to develop personally. In addition, the employee is satisfied and motivated to work for the company, when the employer enables taking up challenges and implementation at work ${ }^{20}$.

Undoubtedly, an important challenge for human resources management is the need for HR departments to take into account the expectations and needs of employees, as remuneration will be the most important for some employees, for others the prestige and, for others, autonomy at work. In the future, HR departments will have to adapt all motivators to the expectations of employees. Thus, only the employment of talented employees will be insufficient, but care will be required to keep employees in the company ${ }^{21}$.

To sum up, it should be stated that motivating is an inseparable element of human resources management in every company's business. Each manager should first get to know his subordinates and then choose appropriate forms of motivation. This will allow effective management of people focused on achieving the set goals of the organization.

\section{ELEMENTS OF FINANCIAL MOTIVATION IN AN ENTERPRISE}

The use of actions related to external motivation by superiors causes employees to develop internal motivation. Therefore, the correct selection and appropriate use of motivators is very important. They should be addressed to a specific person, taking into account the degree of its vulnerability to external impact by means of material and non-material incentives $^{22}$.

Every enterprise in the process of motivating employees uses many instruments, both financial and non-financial, as well as payroll and non-payroll. They are a collection of methods, rules, ways and forms of conduct as well as procedural, structural and organizational solutions that regulate motivation in the organization. Effective motivation is associated with the appropriate selection of these instruments, appropriate to the existing conditions and needs of the company. It is also very important that the set of motivating instruments used by managers should be comprehensive and flexible ${ }^{23}$.

The most important elements of financial motivation that are the subject of consideration include:

1) pay rise,

2) discretionary bonus,

3) bonus depending on the results of work,

4) cash or in-kind reward,

20 A. Dębowski, Bardziej od ludzi liczy się ich zaangażowanie, Dziennik 2008/09/29, s. 14.

${ }^{21}$ What's Next: Future Global Trends Affecting Your Organization, Evolution of Work and the Worker, 2014.

22 A.I. Baruk, Bodźce motywujące wspótczesnych pracowników, „Ekonomika i Organizacja Przedsiębiorstwa" 2010/8 (727), s. 33.

23 A. Pietroń-Pyszczek, Motywowanie pracowników, wskazówki dla menedżerów, Wrocław 2014, s. 27. 
5) other motivators:

- training,

- co-financing for education,

- trips and integration meetings,

- business tools (company car, laptop, telephone),

- life insurance,

- medical care,

- tickets,

- gift vouchers,

- Christmas packages.

The first of these elements is a pay rise, which is associated with an increase in the amount of remuneration paid to the employee each month. Certainly, such an action of the employer will be accepted by the employee with great enthusiasm, but it will not affect the increase of his involvement in the long run. It should be noted that the increase is worth allocating to those employees who are faced with increased requirements in the form of, for example, increased responsibility or the number of new tasks to be implemented. In addition, the level of the increase should be directly related to the employee's work-related expenses.

The discretionary bonus is the monetary amount granted by the manager according to his own criteria. Unfortunately, it is characterized by a large subjectivity of the superior, and its allocation may negatively affect the involvement of other employees who think that their work also deserves to be honored. It should be emphasized that this type of bonus can become an effective motivator only when clear rules for granting it are established ${ }^{24}$.

The next element is a bonus depending on the results of work, which is paid to individual employees based on the work results obtained by them. In this case, specific criteria are applied, about which employees are informed before starting work or a specific task. Often, various types of indicators are also used, such as: revenue, profit, etc. This type of bonus may also depend on the achievement or level of implementation of specific goals that are relevant at the moment in the company. It should be noted that in the case of a properly functioning motivating system, a bonus depending on the results of work is the most effective method of financial motivation in contemporary enterprises. It can generate high employee engagement in the long run. Unfortunately, however, in this case it should be remembered that the efforts of employees will be directed exclusively at the so-called premium elements, while omitting other, perhaps equally important for the functioning of the enterprise $^{25}$. It should be noted, however, that this form of remuneration strongly affects the growth of labor productivity ${ }^{26}$.

The award is connected with the competition system, in which the rules for granting additional remuneration are established. This motivator can exist in conjunction with other motivators used in the enterprise or independently of them. Most often, the announcement of the competition takes place at the beginning of the year. Then, the assessment rules and

\footnotetext{
${ }^{24}$ Own work based on: L. Zbiegień-Maciąg (red.), Nowe tendencje i wyzwania w zarzadzaniu personelem, Kraków 2006, s. 97-98 and: M. Armstrong, Zarzadzanie zasobami ludzkimi, Wydawnictwo Wolters Kluwer, Warszawa 2011, s. 296-298.

${ }^{25}$ Own work based on: L. Zbiegień-Maciąg (red.), Nowe tendencje $i$ wyzwania..., s. 97-98 and: M. Armstrong, Zarzadzanie zasobami ludzkimi..., s. 296-298.

${ }^{26}$ C. Zając (red.), Zarzadzanie zasobami ludzkimi..., s. 146-147.
} 
binding deadlines are passed to the general message. After the competition, the honored employees or even their entire teams receive an additional remuneration or valuable material reward for the results obtained in the specified time covered by the competition ${ }^{27}$.

Despite the high effectiveness of bonus systems as a motivating instrument, non-pay accessories are becoming more and more important. Employers wanting to retain or attract key employees are looking for other methods of motivating employees ${ }^{28}$. Some companies, as part of incentive systems instead of applying various types of bonuses or increases, offer additional benefits to their employees. These include business tools, such as a company car, laptop or telephone. In addition, employers increasingly choose to provide life insurance or medical care to employees as well as members of their families. Some employers also provide various types of tickets, gift vouchers or even holiday packages that are approved by employees.

Due to the needs resulting from working at specific positions, many enterprises organize training for employees or cover the costs of training in whole or in part. Through such activities, managers not only support the development of employees, but also affect the increase of their involvement and thus attachment to the company they work in ${ }^{29}$.

At this stage, it is worth emphasizing that the application of financial motivators by the superiors requires knowledge, skills, experience and sensitivity. At the same time, it becomes necessary for employers and managers to choose the right form and instruments of motivation, tailored to the needs of employees, as well as to internal and external conditions $^{30}$.

In effective personnel policy, the ability to build such an incentive system is important, which responds to the needs of employees and their individual, internal level of motivation $^{31}$. Particularly important in this system is the selection of appropriate motivators, the use of which may encourage employees to work more efficiently and, consequently, increase loyalty to the employer.

\section{APPLICATION OF FINANCIAL MOTIVATORS IN AN ENTERPRISE ON THE BASIS OF EMPIRICAL RESEARCH}

In order to learn about the importance of financial motivation in the company and to verify the hypothesis, it became necessary to conduct primary research. The survey covered employees occupying non-managerial positions in various departments of commercial enterprises, and the selection of these organizations for the study was deliberate. The size of employment was assumed as the selection criterion and therefore the survey covered 10 selected companies operating in the region of Konin and employing over 500 people. The survey was conducted from October to December 2017. The survey was completed as a result of a personal interview.

\footnotetext{
27 Own work based on: L. Zbiegień-Maciąg (red.), Nowe tendencje i wyzwania w zarządzaniu personelem..., s. 97-98 and: M. Armstrong, Zarzadzanie zasobami ludzkimi..., s. 296-298.

${ }_{28}$ D. Mamro, Motywować bez wyjątków, „Marketing w Praktyce” 2008/01, s. 88-89.

${ }^{29}$ Own work based on: Systemy motywacji finansowej pracowników, www.findict.pl and: red. L. Zbiegień-Maciąg, Nowe tendencje i wyzwania w zarzadzaniu personelem..., s. 97-98.

${ }^{30}$ C. Zając (red.), Zarządzanie zasobami ludzkimi..., s. 148-149.

${ }^{31}$ Ibidem, s. 50-51.
} 
Analyzing the results of the conducted research, it is first necessary to present financial motivators that motivate the respondents to the highest degree. The distribution of responses is shown in Figure 1.

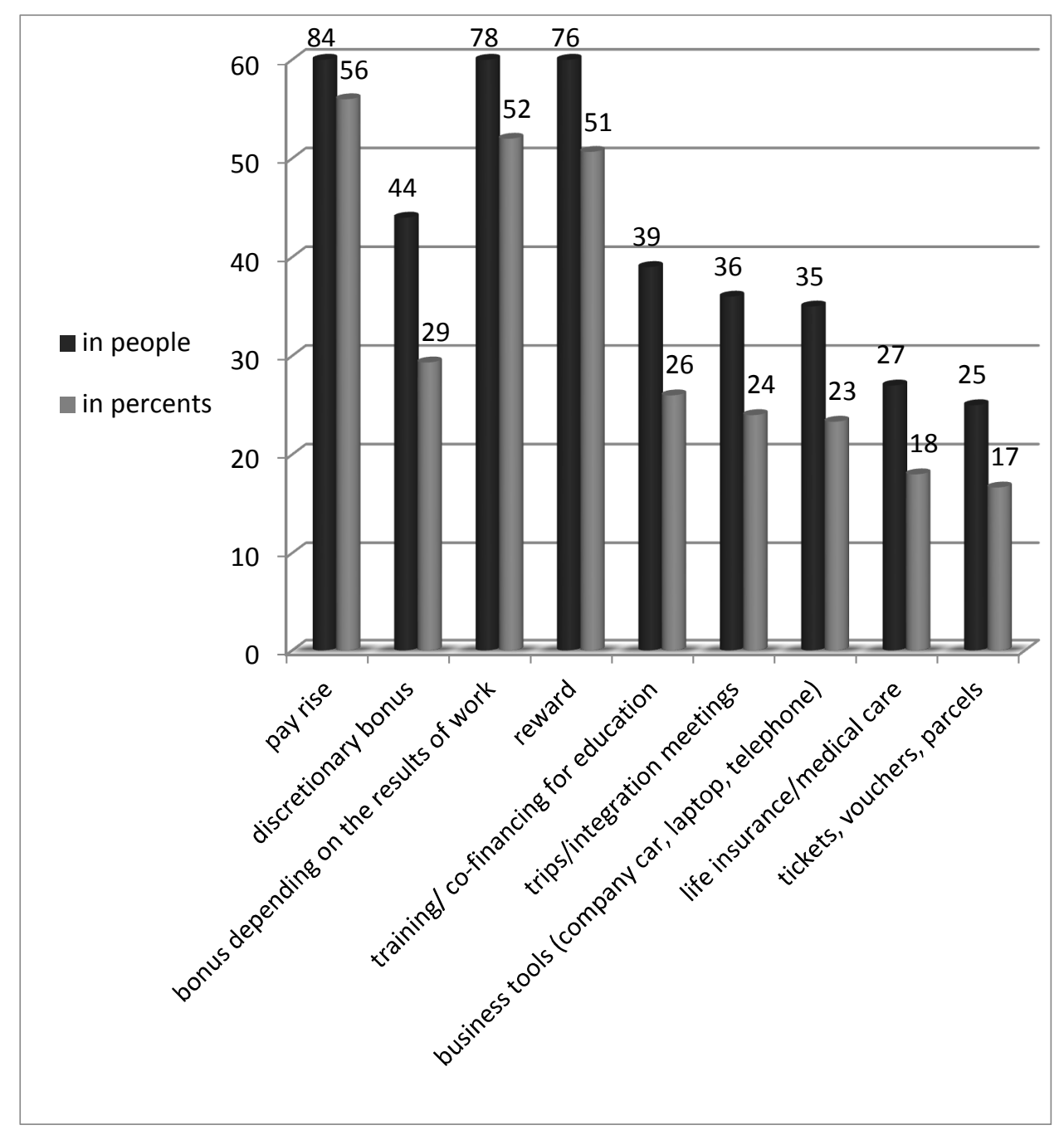

Figure 1. Impact of motivators on motivating employees

Source: own study.

As it can be seen from Figure 1, the surveyed employees first mentioned the increase as the element that motivates them most to work. This group was made up of $56 \%$ of respondents. Next, the following were indicated: reward and bonus depending on the results of 
work, which was indicated by more than half of the respondents. In addition, the discretionary bonus is an important motivator for $30 \%$ of respondents. Subsequently, the respondents mentioned: trainings / co-financing for education (26\%), trips / integration meetings (24\%) and business tools such as: company car, laptop, telephone (23\%). On the other hand, elements which were indicated by less than $20 \%$ of the surveyed employees are: life insurance / medical care and tickets, vouchers, parcels.

Therefore, when analyzing the answers of the surveyed employees regarding the use of financial motivators, it should be stated that employees are motivated by the highest rate of increase and reward, and in the lowest by life insurance / medical care, and tickets, vouchers and parcels.

Respondents during the study were also to indicate the way they prefer to be motivated. Respondents most often indicated an individual way of motivating, although there were also those for whom team-based motivation was important. The distribution of responses is shown in Figure 2.

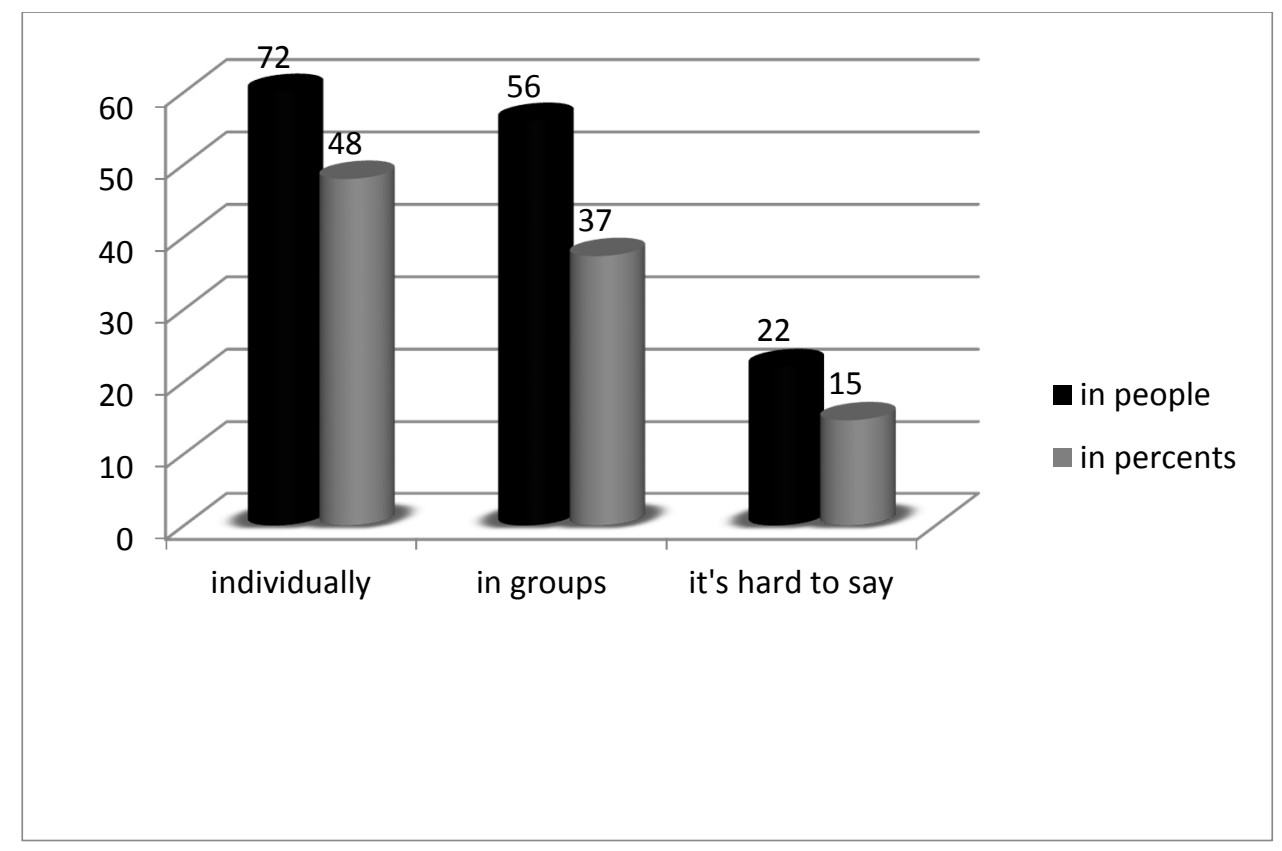

Figure 2. Individual or group motivation in the opinion of respondents

Source: own study.

Based on the above figure, it can be noticed that the respondents prefer an individual way of motivating, because almost half of the respondents gave such an answer. However, almost $40 \%$ of people considered the motivators assigned to the whole group as the best way to motivate. At the same time, $15 \%$ of the respondents could not give a definite answer. 
In the study, it was also important to check which of the mentioned financial motivators are used in the surveyed companies as part of employees motivation. The distribution of answers is shown in Figure 3.



Figure 3. Financial motivators used in enterprise

Source: own study.

Analyzing Fig. 3, it can be stated that in the surveyed enterprises, employers motivate employees most often with a bonus depending on the results of work, which was indicated by almost $60 \%$ of employees. In the next step, employees are also offered a discretionary bonus, which was mentioned by $1 / 3$ of the respondents. At the same time, business tools such as: a company car, laptop or phone are used by $27 \%$ of enterprises, and training / cofinancing for education or various types of awards are offered to employees in $1 / 4$ of the surveyed enterprises. It should be noted that research has confirmed that the pay rise is 
a rarely used motivator. According to the obtained results, it is used by only $15 \%$ of employers. The respondents also confirmed that other elements such as life insurance / medical care or trips / integration meetings belong to those motivators from which employers are reluctant.

The survey shows that it is analogously $12 \%$ and $11 \%$ of companies. In addition to the motivating elements mentioned above, respondents were also able to assess the use of: subscriptions, vouchers or parcels handed over by the employer to employees. Unfortunately, it turns out that the analyzed enterprises are less interested in motivating employees by means of these elements.

By making their own observations and interpretations of the results of empirical studies obtained, conclusions were formulated that allowed for a positive verification of the hypothesis defined in the introduction of the article. The established hypothesis was confirmed by the analysis of the distribution of respondents 'answers in the question about determining the impact of selected motivators on the level of employees' involvement in work and in the question regarding the indication of financial motivators that are used in the surveyed companies. Interpretation of the results showed quite clearly that financial motivators are an important element of the employee motivation process. At the same time, the surveyed employers often emphasized that they were very keen to apply employee accounting for the results and allocate the related bonus to them.

The surveyed enterprises from the region of Konin wanting to have more influence on the motivation of their employees should more often use financial motivators, such as a raise or reward, because according to the surveyed it is these elements that motivate them to the highest degree. However, the survey shows that employers prefer to reckon employees for the results and to assign them a bonus. This is certainly due to the need to achieve specific results by individual employees or even their entire teams.

\section{SUMMARY}

Properly motivated, with appropriate qualifications and experience, the employee is constantly sought after in the labor market, especially by companies striving to develop and achieve their goals. Contemporary managers have at their disposal various motivators that they can use as part of managing subordinates. These include primarily financial motivators, which in contrast to non-financial incentives, they are indicated as elements that encourage workers to work in the highest possible way.

Unfortunately, motivational systems used in enterprises, although they are supposed to influence employees 'engagement and should be perceived positively, very often cause an increase in employees' claims. In addition, even the best financial motivators and attractive remuneration may not be properly assessed and contribute to employee dissatisfaction. It is important, therefore, that in particular financial incentive systems in the company are constructed correctly and allow long-term cooperation with the employee.

The motivation expectations of employees are constantly changing. The studies carried out show that incentives for the most desired motivators employed by enterprises in the region of Konin include a raise and a reward, followed by other types of motivators. Unfortunately, as research in enterprises shows, the most frequently applied bonus is a workrelated bonus, which, according to the results of research, motivates half of the employees 
surveyed. Therefore, the less frequently used motivators are those most desirable by employees. This result is quite puzzling, but it may be related to the fact that employees are looking for other motivators than those to which they have already got used to.

To sum up, employers in the Konin region, as part of personnel activities, should conduct systematic employee satisfaction surveys and make changes based on the results obtained in the personnel strategy, and in particular the strategy of motivating employees, so that the employees' needs are best satisfied and, as a result, their satisfaction increases and results in higher efficiency at work.

\section{REFERENCES}

1. Armstrong M., Taylor S., Zarzadzanie zasobami ludzkimi, Wydawnictwo Wolters Kluwer, Warszawa 2016.

2. Armstrong M., Zarzadzanie zasobami ludzkimi, Wydawnictwo Wolters Kluwer, Warszawa 2011.

3. Baruk A.I., Bodźce motywujące wspótczesnych pracowników, „Ekonomika i Organizacja Przedsiębiorstwa" 2010/8 (727).

4. Dębowski A., Bardziej od ludzi liczy się ich zaangażowanie, ,Dziennik” 2008/09/29.

5. Gableta M. (red.), Potencjat pracy przedsiębiorstwa, Wydawnictwo Akademii Ekonomicznej we Wrocławiu, Wrocław 2006.

6. Gadomska-Lila K., Dopasowanie organizacyjne. Aspekt strategii, kultury organizacyjnej i zarzadzania zasobami ludzkimi, Wydawnictwo Difin, Warszawa 2013.

7. Jasiakiewicz M., Soroka J. M., Psycho-społeczne uwarunkowania kierowania ludźmi w organizacji, Wydawnictwo Wyższej Szkoły Zarządzania i Finansów we Wrocławiu, Wrocław 2001.

8. Kozioł L., Piechnik-Kurdziel A., Kopeć J., Zarzadzanie zasobami ludzkimi. Teoria i praktyka, Wydawnictwo Biblioteczka Pracownicza, Warszawa 2006.

9. Mamro D., Motywować bez wyjątków, „Marketing w praktyce” 2008/01.

10. Pawłowska B., Teorie motywacji, Katedra Socjologii Organizacji i Zarządzania Uniwersytetu Łódzkiego, Łódź 2009, www.soc-org.edu.pl.

11. Pietroń-Pyszczek A., Motywowanie pracowników, wskazówki dla menedżerów, Wydawnictwo MARINA, Wrocław 2014.

12. Pocztowski A., Zarzadzanie zasobami ludzkimi. Strategie - procesy - metody, Polskie Wydawnictwo Ekonomiczne, Warszawa 2012.

13. Stoner J.A.F., Freeman R.E., Gilbert D.R. jr., Kierowanie, Polskie Wydawnictwo Ekonomiczne, Warszawa 2011.

14. Systemy motywacji finansowej pracowników, www.findict.pl.

15. The Economist Intelligence Unit, What's Next: Future Global Trends Affecting Your Organization, Evolution of Work and the Worker, New York, 2014.

16. Walkowiak R, Czaplicka-Kozłowska I.Z., Kozłowski A.J., Stachowska S., Zarzadzanie potencjałem społecznym organizacji, Uniwersytet Warmińsko-Mazurski w Olsztynie, Olsztyn 2013.

17. Zając C. (red.), Zarządzanie zasobami ludzkimi, Wydawnictwo Wyższej Szkoły Bankowej, Poznań 2011.

18. Zbiegień-Maciąg L. (red.), Nowe tendencje $i$ wyzwania w zarzadzaniu personelem, Oficyna Ekonomiczna, Kraków 2006. 


\section{ZNACZENIE MOTYWATORÓW FINANSOWYCH W PROCESIE MOTYWOWANIA PRACOWNIKÓW W PRZEDSIĘBIORSTWACH REGIONU KONIŃSKIEGO}

Problematyka motywowania dotyczy każdej organizacji, przede wszystkim ze względu na zróżnicowanie dostępnych motywatorów oraz trudności wynikające z ich stosowania, w szczególności te związane z dopasowaniem do potrzeb i oczekiwań pracowników. Jednocześnie, każdy system motywacyjny składający się z motywatorów finansowych i pozafinansowych generuje koszty finansowe dla przedsiębiorstwa. Niezależnie bowiem, od rodzajów wykorzystywanych motywatorów (płacowych, pozapłacowych, finansowych, pozafinansowych) menedżerowie muszą przygotować przedsiębiorstwo na poniesienie konkretnych nakładów finansowych. Konieczne jest zatem poszukiwanie takich motywatorów, które nie tylko zyskają akceptację pracowników, ale przede wszystkim wpłyną na ich zaangażowanie w realizację celów, do osiągnięcia których dąży organizacja i jednocześnie będą stanowiły optymalne obciążenie finansowe dla przedsiębiorstwa. Ważną rolę $\mathrm{w}$ całym procesie odgrywa motywowanie finansowe, które wiąże się z nakładami finansowymi ponoszonymi przez przedsiębiorstwo, ale jednocześnie w najwyższym stopniu potrafi pobudzić pracowników do efektywnej pracy. Stosowanie motywatorów w przedsiębiorstwach może wynikać ze stosowania rozmaitych systemów i nie zawsze prowadzić do podejmowania przez przedsiębiorstwo skutecznych działań na rynku. Celem opracowania jest przedstawienie wykorzystania konkretnych motywatorów finansowych w przedsiębiorstwach regionu konińskiego w opinii zatrudnionych pracowników. W artykule postawiono hipotezę, że motywatory finansowe są $\mathrm{w}$ przedsiębiorstwach ważnym elementem procesu motywowania pracowników, a pracodawcy najczęściej stosują rozliczanie pracowników za wyniki i przydzielanie im związanej z tym premii. Opracowanie częściowo jest oparte na wynikach z przeprowadzonych badań empirycznych, co pozwala na ukazanie problematyki w ujęciu praktycznym.

Słowa kluczowe: motywacja, firma, pracownik, finanse.

DOI: 10.7862/rz.2018.mmr.57

Tekst złożono do redakcji: lipiec 2018 r.

Tekst przyjęto do druku: grudzień 2018 r. 